\title{
Exploring Liquidity Risk and Interest-Rate Risk: Implications for Profitability and Firm Value in Nigerian Banks
}

\author{
Olalere Oluwaseyi Ebenezer ${ }^{1, *}$, Md. Aminul Islam ${ }^{1}$, Wan Sallha Yusoff ${ }^{1}$ and Farid \\ Ahammad Sobhani ${ }^{2}$
}

${ }^{1}$ School of Business Innovation and Technopreneurship, Universiti Malaysia Perlis, Jalan Kangar-Alor Setar, Taman Pengkalan Jaya, 01000, Kangar, Perlis, Malaysia

${ }^{2}$ School of Business and Economics, United International University, Dhaka, Bangladesh

\begin{abstract}
The purpose of this paper is to examine the effects of liquidity risk and interest rate risk on profitability and firm value, current studies are typically limited in emerging markets. This study employs a panel data estimation technique and a sample of 16 banks operating in Nigeria over the period from 2009 to 2017 making up to 144 observations. The findings of the study reveal that liquidity risk (loan to deposit ratio and liquid asset ratio) have a significant negative effect on firm value, the net interest margin and GDP have a negative significant impact on firm value for Nigerian banks. The loan to deposit ratio have a negative significant effect on firm value while the liquid asset ratio have a positive effect on firm value. The net interest margin have a negative significant effect on firm value while the asset interest margin have a positive significant impact on firm value. The GDP and inflation both have a positive significant relationship with firm value. The liquidity risk (loan to deposit ratio and liquid asset ratio) have a significant negative impact on return on equity of Nigerian banks. The GDP growth rate have a positive significant effect on the value of firm. Hence, this empirical study emphasizes and contributes to the dynamic role of liquidity risk and interest-rate risk and it's implication on profitability and firm value of banks in Nigeria and suggest that further study can explore a comparative study between Nigeria and financial firms in developed economy.
\end{abstract}

Keywords: Firm value, profitability, liquidity risk, interest-rate risk, Nigeria.

\section{BACKGROUND}

The aftermath of financial turmoil that occurred in 2007 revealed the significance of the sound liquidity risk management in financial institutions. Thus, credit crisis was the sole causes of the financial crisis that later transformed into a liquidity crisis. The subprime crisis that started in the first half of 2007 is due to the crash of the credit quality of US subprime residential mortgages. Indeed, what triggers the liquidity crisis was the rise in delinquencies in mortgage lending and the decline in housing prices in the United States in 2007. Surprisingly, bankruptcy of banks, nationalizations and a decline in financial performance of large financial firms was not only limited to financial crisis occurrence. The deterioration of international stock markets, the drying of liquidity in interbank markets spilled over into a sovereign debt crisis in several European countries in early 2010 (Greece, Portugal, Ireland, Italy and Spain) which was also caused by financial crisis (Moro, 2013). Since it is considered to be the most severe financial crisis since the Great Depression (Brunnermeier 2009), the global financial crisis has demonstrated the importance of establishing a level of liquidity sufficient to cope with adverse conditions.

\footnotetext{
${ }^{*}$ Address correspondence to this author at the School of Business Innovation and Technopreneurship, Universiti Malaysia Perlis, Jalan Kangar-Alor Setar, Taman Pengkalan Jaya, 01000, Kangar, Perlis, Malaysia; E-mail: oluwaseyi218@gmail.com
}

Empirical studies shows that liquidity risk negatively affects banks through idiosyncratic and systematic channels which raised a doubt about their current risk management practices (Hong et al., 2014). Liquidity was recognized as a significant determinant which drives the risk-taking behaviour of banks and consequently impacts adversely the stability of the entire financial system (Khan et al., 2016). Such risktaking activities of financial institutions are facilitated by deregulation and competition between financial institutions (Laeven et al., 2016). The funding and risk management structure of banks have been altered as a result of high competition for consumer deposits, a wide array of funding products in wholesale and capital markets with technological advancements (Akhtar, 2007). Hence, the Basel III Accord (2010) respond to these issues with the introduction of the new liquidity requirements specifically tailored for banks to the present risk management practices of banks in both supervisory and regulatory frameworks to address banks' liquidity risk (Vazquez \& Federico, 2015).

The sensitivity of banks to risk as financial intermediaries is vital to the stability and health of the financial system (Barth, Caprio \& Levine, 2004). The emphasis on interest rate risk exposure is primarily rooted in the nature of banks. Hence, interest rate risk arises from the fact that the assets and liabilities of a bank usually react differently to interest rate movements (Triantis, 1999). Several factors such as 
the high volatility of interest rates, the dramatic increase in the use of corporate debt through shortterm borrowing have contributed to the recent prominence of interest rate risk in commercial banks. Excessive interest rate risk exposure can significantly jeopardize the bank's incomes and capital base. The variations in the interest rates influence the bank's earnings and change its net interest revenues and the level of other interest-sensitive earnings and operative costs. The financial assets and liabilities primarily hold by banks in their balance sheets are often fixed in nominal terms and especially sensitive to interest rate changes. Therefore, the traditional function of banks involves performing a maturity transformation using short-term deposits to finance long-term loans. This repeatedly result in mismatch between the maturity or time to re-pricing of their assets and liabilities which exposes banks to repricing risk, often seen as the major source of the interest rate exposure of the banking system.

Recognizing the importance of this inherent risks, the existing literature offers little consensus regarding the nexus between liquidity risk, interest-rate risk, profitability and firm value. The study is motivated on the grounds that interest rate risk is associated with the credit facilities which accounts for a lion share of bank's profitability and that the classic functions of banks are based on liquidity. This study fills the gaps in empirical literature by focusing on both liquidity risk and interestrate risk and how it influences the short and long term performance of banks. The empirical findings will help banks in emerging and developing economies to identify the effect of liquidity risk and interest rate risk and gear up bank management to monitor and control the risk in a timely and comprehensive manner. The remaining sections of this paper is organised as follows: section two focuses on literature review, section three discusses the methodology, section four presents the findings and the conclusion ends this research.

\section{REVIEW OF RELATED LITERATURE}

Liquidity in financial markets has multiple connotations which signifies the aptitude of a financial firm to keep up all the time a balance between the financial inflow and outflow over time (Akhtar, Ali \& Sadaqat, 2011). The theoretical prediction explicated in the study by Acharya and Naqvi (2012) provides evidence that a significant amount of deposits attracted by banks lowers funding liquidity risk and then encourages banks to take more risks. What motivates and/or drives bank executives in taking more risks is as a result of seeking higher compensations and the review of banks to choices taken by executives is very expensive. One of the critical roles of banks which involves liquidity creation and delegated monitoring was clearly highlighted by the financial intermediation theory (Diamond, 1984; Berger \& Bouwman, 2009). The study by Berger and Bouwman (2009) and Holmstrom and Tirole (1998) explained that banks liquidity creations to customers emerge by ensuring sufficient funds are made available for the customers withdrawal needs. Likewise, the transformation of risks by financial firms helps to extend riskless deposits aiming at financing risky loans while earning returns from the risk transfer functions. Hence, the role of banks in liquidity provision necessitates that banks maintain a reasonable amount of liquidity to discharge their obligations promptly. Financial institutions hedged against liquidity shortfalls by ensuring prompt and consistent liquidity creation by maintaining cash and cash equivalents.

Theoretical arguments sustains that high level of assets liquidity can increase the risk of banks, even though there is a regulatory requirements for banks to maintain a liquidity buffer to mitigate liquidity risk and to insure against liquidity shocks. The study by Hong et al. (2014) explicated that the occurrence of bank failure over the period 2009 to 2010 in the aftermath of the 2007-2008 financial crisis was due to systematic liquidity risk. Hence, liquidity risk could lead to bank failures through systematic and idiosyncratic channels. In addition, the study by Acharya and Naqvi (2012) and Wagner (2007) have revealed that short-term liquidity have implications for bank risk-taking and bank stability. The study by Bordeleau and Graham (2010) empirically analysed the effect of liquid assets holding on the profitability of banks for a sample of large U.S. and Canadian banks, and the result suggested that profitability is improved for banks that hold some liquid assets. The study by Lartey et al., (2013) which employed listed banks in Ghana examined if there is a relationship between the liquidity and the profitability and the study found that there is a very weak positive relationship between the liquidity and profitability of the listed banks in Ghana. The study by Abreu and Mendes (2001), who investigated banks in Portugal, Spain, France and Germany, find that the loans-toassets ratio, as a proxy for risk, has a positive impact on the profitability of bank.

The seminal work of Bourke (1989) conducted to examine liquidity risk and profitability nexus revealed a 
positive and significant effect. Conversely, the study conducted by Molyneux and Thornton (1992) found a positive association between liquidity risk and profitability. However, studies conducted in China and Malaysia found that the level of banks' liquidity shows no correlation with the performance of the banks (Said \& Tumin, 2011). The study by Kosmidou, Tanna and Pasiouras (2005) found a significant positive relationship between liquidity and bank profits. An indirect relationship between the liquidity level and performance was found in a study by (Guru, Staunton \& Balashanmugam, 2002). On the other hand, TrujilloPonce (2013) demonstrated (using a sample of Spanish banks in the period of 1999-2009) that liquidity risk was substantially correlated with performance in Spanish banks. In particular, this concerned the relationship between loans granted and total assets as well as the share of deposits in total liabilities. According to the author, the growth in these indices is accompanied by improving performance of Spanish banks. Prior empirical studies such as Bourke (1989), Molyneux and Thornton (1992) and Ferrouhi (2014) also examines the effect of liquidity and bank performance and found both positive and negative significant effect.

On the other hand, the prevalence of interest rate risk on bank returns has been the focus of a considerable amount of literature over the last three decades. The majority of this research, mostly based on developed markets, has documented a significant and negative effect of interest rate fluctuations on bank returns (e.g., Lynge \& Zumwalt 1980; Elyasiani \& Mansur 1998; Saporoschenko, 2002). The seminal work of Flannery and James (1984) provided substantial evidence that maturity mismatch between assets and liabilities may be used to explain crosssectional variation in bank interest rate sensitivity. This finding has since been supported later on by, among others, (Kwan, 1991; Akella \& Greenbaun, 1992). The management of interest rate risk has gained more prominence in recent years due to the fact that interest rates and financial market conditions have become considerably more volatile. Similarly, the net interest income, which directly depends on interest rates, still remains as the most important source of bank revenue despite the rising weight of fee-based income. Hence, the incidence of interest rate risk makes the structure, direction and magnitude of changes in interest rate relevant for healthy performance of banks.

In a bid to manage inherent risks in financial firm, recent decades have seen a proliferation in the use of new and complex financial instruments such as swaps, futures, options and forwards (Mallin et al., 2001) and interest rate risk is probably the most important of all the financial risks. The study by Kolapo and Fapetu (2015) contends that the habitual nature of banks heightens their exposure to interest rate risk due to their core function of financing loans and advances of long-term nature with demand deposits, suggesting that short-term liabilities are matched with long-term assets. The study by Patnaik and Shah (2004) assessed the influence of interest rate risk in the context of Indian banks. The empirical study found evidence of substantial exposure to interest rates and postulates that some banks seems to have a rather different exposure to interest rate risk because they might hold similar portfolios of government securities. Hence, the empirical results shows a striking feature as heterogeneity is seen across banks. The study by Memmel and Raupach (2010) explored the exposure of banks to interest rate risk in addition to their earnings from term transformation using a data set of German banks. Empirical findings from the study revealed that for the sample period 2005 to 2009, the systematic factor for the exposure to interest rate risk rises and falls in synchronization with the shape of term structure.

Furthermore, Zagonov, Keswani and Marsh (2009) conducted a study to show how banks regulate their interest rate profile. The study found that majority of the banks are negatively affected by adverse interest rate movements, suggesting the failure to adopt comprehensive hedging strategies by the banks. The study also perceived that greater levels of economic freedom, better governance, and higher quality of government supervision are all associated with lower bank exposure to interest rate risk. However, prior empirical studies such as Demirguc and Huizinga (1999) and Nofiyanti (2014) found a positive relationship with interest rates and profits, particularly in emerging and developing market economies while studies such as Ebrahim et al., (2013), Aruwa and Musa (2014) found a negative significant relationship between interest rate risk and profitability. On the contrary, the study by Albertazzi and Gambacorta (2009) concluded that short-term interest rates have no significant impact on income margins for a group of $O E C D$ countries. Hence, there has been little empirical discussion about the relationship between liquidity risk and firm value nexus in the context of emerging countries such as Nigeria and as such, diversity of studies has created a wide gaps in extant studies. 
Thus, the main objective of this study is to explore liquidity risk and interest-rate risk and its implication on profitability and firm value of banks.

\section{Data Sources and Definition of Variables}

This study analyses panel data on 16 commercial banks in Nigeria for the period 2009 - 2017. The dataset on the liquidity risk, interest rate risk and control variables includes loan and advance to deposit ratio, liquid asset to gross loan ratio, net interest margin, changes in interest rates, bank size are extracted from the financial reports of individual banks. The macro-economic variables such as GDP growth rate and inflation are extracted from the World Bank Development Indicator. The macroeconomic variables were included in the model as prior studies affirms its direct or indirect non-linear relationships with the bankspecific variables. The study by Staikouras and Wood (2003) pointed out that inflation may have direct effects (e.g. rise in the price of labour) and indirect effects (e.g. changes in interest rates and asset prices) on the profitability of the banks.

\section{Firm Performance Variable}

Enterprise value is employed in this study and is generally used in identifying undervalued firms, believed to be a robust market value proxy (Lifland 2011), because it captures the actual and overall market value of firm as a whole business and it's an economic measure useful for the valuation of firm (Bhullar \& Bhatnagar 2013). The proxy put into consideration debt obligations, non-controlling minority interest and excess cash in valuing a firm. Therefore, the enterprise value divided by Earnings before interest, taxes, depreciation and amortization (EV/EBITDA) represents the proxy for firm value. Enterprise value is measured as equity value + total debt- cash \& cash equivalents + preferred stock + minority interest.

According to previous studies that have used return on assets, ROA is measured as the net income for the year divided by total assets. It is typically the proxy by net income divided by total assets, which allows banks to have benefits of constant stable incomes. Prior studies that have use ROA as profitability variable includes (Arif \& Anees, 2012; Alper \& Anbar, 2011; Tafri et al., 2009). Additionally, the return on equity (ROE) is measured by net income over total equity of banks. The return on equity assess the financial return of a shareholder's investment and indicates how well a firm uses shareholders fund to generate profit (Tafri et al., 2011; Alper \& Anbar, 2011; Saeed, 2013).

\section{Risk Components Variables}

Liquidity risk in this study is proxy as the ratio of bank's total loan and advances to total deposits and liquid asset to total asset ratio, which is affirm other studies (Spathis et al., 2002; Al-Tamimi et al., 2015; Said \& Tumin, 2011; Marozva, 2015; Saeed, 2013). Thus, the bank liquidity risk decreases as the proportion of the liquid asset's increase (Said \& Tumin, 2011; Tafri et al., 2009). Hence, the expected relationship with financial performance is negative.

Since commercial banks are sensitive to changes and fluctuations in interest rates, interest rate risk is proxy in this study as the net interest margin and the asset interest yield. The NIM is the net interest income divided average interest earning assets. Hence, the net interest margin measures the difference between the interest income generated by banks and the amount of interest paid out to their lenders, relative to the amount of interest earning assets (Dumicic \& Ridzak, 2013; Khrawish, 2011; Ongore \& Kusa, 2013; Hamadi \& Awdeh, 2012; Tarus et al., 2012; Kalluci, 2010). While the asset interest yield is proxy by interest income to total asset ratio. This study expect a positive relationship between interest rate risk, profitability and firm value.

\section{Control Variables}

Usually, bank size is often measured by using natural log total assets and is used as a control variable in this study (Tafri et al., 2009; Akhtar et al., 2010; Athanasoglou, Brissimis, \& Delis, 2008; Tafri et al., 2011; How et al., 2005). In most cases, bank size is generally used to capture potential economies or diseconomies of scale. In relation to financial performance, usually it is anticipated that the relationship between banks size and profitability is positive (Smirlock, 1985).

Favourable economic growth in any country spurs households' income and other businesses and the direction of economic progress is as a result of growth in GDP. The effect of economic environment on banks financial performance is usually controlled by employing the growth as the macroeconomic variable as used by (Tafri et al., 2011; Dumicic \& Ridzak, 2013; Sinha \& Sharma, 2016). Proxy by GDP growth, it is expected to have a positive relationship with bank profitability and firm value 
Furthermore, the inflation rate (consumer price index) is used in this study as a control variable. The study by Curak et al. (2013) explicates that low level of inflation rate and a stable price suggest a positive economic growth and possibly raises the profitability of banks. The study by Tinoco-Zermeno et al. (2014) posits that the potentials of banks to generate higher profit and improve firm value is often affected by the dynamics of inflation rates. The expectation of this study is a negative nexus between inflation rate, profitability and firm value.

\section{METHODOLOGY}

Panel data analysis is employed in this study as the estimation and it's a special techniques which accounts for the time-series and cross-sectional dimension of the dataset. By implication, it gives more informative data with less variability but less collinearity among the variables and substantially reduce the problems that arise from omitted variables. Hence, panel data models are mostly estimated using either fixed effects or random effects models.

\section{$\mathrm{H}_{1}$ : Liquidity Risk Significantly Influences the Profitability and Value of Firm}

The first hypotheses in this study explicates how liquidity risk affects the profitability and firm value of commercial banks in Nigeria. Empirical studies argues that liquidity risk is a vital internal bank profitability determinant due to its ability to become a source of bank failures (Athanasoglou, et al. 2006). This occurs because of probable incapability of a bank to fund rises on the assets' side of the balance sheet or in accommodating reductions in liabilities. When the liquidity needed to fund illiquid asset position cannot be obtain, the profitability of is often threatened. Meanwhile, some prior studies found a positive significant influence of liquidity risk on financial performance (Naceur \& Kandil, 2008; Distinguin et al. 2012). And some found a negative impact of liquidity risk on bank performance (Marozva, 2015; Athanasoglou et al., 2006; Arif \& Anees, 2012). Hence, this study postulate a significant relationship between liquidity risk, profitability and firm value

\section{$\mathrm{H}_{2}$ : Interest Rate Significantly Affects Profitability and Firm Value}

Fluctuations and changes in interest rate could lead to a mismatch between interest paid on deposits and interest received on loans (Aruwa \& Musa, 2014). Theoretical arguments sustains that due to interest rate risk, investors are likely to experience losses due to factors that affect the overall performance of the financial markets. More importantly, the net interest margin of the banking sector could be exposed to interest rate changes for a period if a large number of banks, presumably responding to the same or similar market signals, choose to take on similar exposures. Some prior studies found that interest rate risk have a negative impact on financial performance of banks (Aruwa \& Musa, 2014; Nofiyanti, 2014; Yousfi, 2012). Hence, the study postulate significant nexus between interest rate risk, profitability and firm value of banks.

$$
\begin{aligned}
\boldsymbol{F} V_{i t}= & \beta_{0}+\beta_{1} L D_{i t}+\beta_{2} L A T A_{i t}+\beta_{3} N I M_{i t}+\beta_{4} A I Y_{i t} \\
& +\beta_{5} S I Z E_{i t}+\beta_{6} G D P_{i t}+\beta_{7} I N F L_{i t}+\varepsilon_{i, t} \\
\boldsymbol{R O A}_{i t}= & \beta_{0}+\beta_{1} L D_{i t}+\beta_{2} L A T A_{i t}+\beta_{3} N I M_{i t}+\beta_{4} A I Y_{i t} \\
& +\beta_{5} S I Z E_{i t}+\beta_{6} G D P_{i t}+\beta_{7} I N F L_{i t}+\boldsymbol{\varepsilon}_{i, t} \\
\boldsymbol{R O E}_{i t}= & \boldsymbol{\beta}_{\mathbf{0}}+\boldsymbol{\beta}_{\mathbf{1}} L D_{i t}+\boldsymbol{\beta}_{\mathbf{2}} L A T A_{i t}+\boldsymbol{\beta}_{\mathbf{3}} N I M_{i t}+\boldsymbol{\beta}_{4} A I Y_{i t} \\
& +\boldsymbol{\beta}_{5} S I Z E_{i t}+\boldsymbol{\beta}_{\mathbf{6}} G D P_{i t}+\boldsymbol{\beta}_{7} I N F L_{i t}+\boldsymbol{\varepsilon}_{i, t}
\end{aligned}
$$

Where FV represents firm value, ROA represents return on asset, $R O E$ represents return on equity, while the liquidity risk contains the loan to deposit ratio and liquid asset to total asset of bank, while interest-rate risk contains net interest margin and asset interest yield ratio, $i$ at time $t$. Control-variables includes bank size, GDP growth and inflation.

\section{RESULTS AND DISCUSSION}

\section{Descriptive Statistics}

The Table 1 below summarize the descriptive statistics of the variables of the Nigerian commercial banks.

This table summarizes the mean and standard deviation of the dependent and independent variables used in the study for the Nigerian banks. The descriptive statistics revealed that firm value (FV) of Nigerian banks has a mean of $0.1068(10 \%)$ while the return on assets of Nigerian banks has a mean of 2 per cent. Furthermore, the return on equity of Nigerian banks has a mean of 6 per cent while the loan to deposit ratio averagely stood at 66 per cent for Nigerian banks. However, the average liquid to total asset ratio for Nigerian bank is 16 per cent. In addition, the average net interest margin of Nigerian banks stood at 8 per cent while the average asset interest yield of Nigerian banks is 8 per cent. Also, the average size of Nigerian commercial banks is approximately 
Table 1: Summary of Descriptive Statistics

\begin{tabular}{|c|c|c|c|}
\hline \multirow{2}{*}{ Variables } & No. & Mean & Sigerian Banks \\
\cline { 2 - 4 } & 144 & .10680 & .05283 \\
\hline \hline FV & 144 & .02047 & .03039 \\
\hline ROA & 144 & .05957 & .40045 \\
\hline ROE & 144 & .65569 & .17860 \\
\hline LD & 144 & .15916 & .09796 \\
\hline LATA & 144 & .07557 & .03203 \\
\hline NIM & 144 & .08421 & .03289 \\
\hline AIY & 144 & .17019 & .03151 \\
\hline SIZE & 144 & .02199 & .01665 \\
\hline GDP & 144 & .11788 & .02898 \\
\hline INFL & . & & \\
\hline
\end{tabular}

NOTE: $\mathrm{FV}=$ Firm value. $\mathrm{LD}=$ Loan to deposit ratio. LATA $=$ Liquid asset to total asset ratio. NIM $=$ Net Interest Margin. AIY = Asset Interest Yield. SIZE $=$ size of banks. GDP = growth of GDP. INFL = inflation.

N17 million and the average GDP growth rate stood at 2 per cent for Nigeria during the period of study. Finally, the average inflation rate in Nigeria is 12 per cent during the period of study. This suggest that the Nigeria economy has witness a significant and rapid increase in inflation during the period of study.

\section{Panel Unit Roots Test}

Time series data are often presume to be nonstationary and the presence of non-stationary variables might result in spurious regression results. Therefore, the study conducted a panel unit roots test to check the stationary and/or the presence of unit root in the time series data. As shown in Table 2 below, the study use the ADF-Fisher with AIC criterion which assumes individual unit roots process and uses chi square test statistics. Therefore, the results indicated that majority of the variables are stationary and significant at $1^{\text {st }}$ difference with intercept only.

\section{Panel Data Analysis}

A panel data estimation is employ in this study which indicates a special techniques which accounts for the time-series and cross-sectional dimension of the

Table 2: ADF Unit Root Test based on AIC Selection Criteria

\begin{tabular}{|c|c|c|c|c|c|c|}
\hline \multirow{2}{*}{ Var. } & \multicolumn{3}{|c|}{ With Intercept only } & \multicolumn{3}{|c|}{ With Intercept and Trend only } \\
\hline & Level & $1^{\text {st }}$ Diff & I(d) & Level & $1^{\text {st }}$ Diff & $\mathrm{I}(\mathrm{d})$ \\
\hline FV & $54.6341^{* * *}$ & & $\mathrm{I}(0)$ & $49.9683^{* *}$ & & $\mathrm{I}(0)$ \\
\hline ROA & $99.1799^{\star * *}$ & & $\mathrm{I}(0)$ & $71.3705^{\star * *}$ & & $\mathrm{I}(0)$ \\
\hline ROE & $81.8463^{* * *}$ & & $\mathrm{I}(0)$ & $42.7150^{*}$ & & $\mathrm{I}(0)$ \\
\hline LD & 37.2739 & $77.4021^{* * *}$ & $\mathrm{I}(\mathrm{d})$ & 32.7842 & $69.7038^{* * *}$ & $\mathrm{I}(0)$ \\
\hline LATA & $49.1606^{\star *}$ & & $\mathrm{I}(0)$ & $62.3432^{* * *}$ & & $\mathrm{I}(0)$ \\
\hline NIM & $86.3635^{\star \star *}$ & & $\mathrm{I}(0)$ & $74.0396^{\star * *}$ & & $\mathrm{I}(0)$ \\
\hline AIY & $55.7748^{* * *}$ & & $\mathrm{I}(0)$ & $88.1042^{* * *}$ & & $\mathrm{I}(0)$ \\
\hline SIZE & $64.5516^{* * *}$ & & $\mathrm{I}(0)$ & 19.5484 & $53.7915^{* * *}$ & $\mathrm{I}(0)$ \\
\hline GDP & 26.1968 & $97.0970^{* * *}$ & $\mathrm{I}(\mathrm{d})$ & $90.5030^{* * *}$ & & $\mathrm{I}(0)$ \\
\hline INFL & 12.3888 & $56.7297^{* * *}$ & $\mathrm{I}(\mathrm{d})$ & 3.98107 & $67.0047^{* * *}$ & $\mathrm{I}(0)$ \\
\hline
\end{tabular}

Notes: $\mathrm{t}$-stat $=$ t-statistics. I $(\mathrm{d})=$ integrated by the order of $d . \mathrm{FV}=$ Firm value. LD = Loan to deposit ratio. LATA $=$ Liquid asset to total asset ratio. NIM $=$ Net Interes Margin. AIY = Asset Interest Yield. SIZE = size of banks. GDP = growth of GDP. INFL = inflation.

The null hypotheses shows that the data are non-stationary, or contains a unit root. ${ }^{* * *},{ }^{* *},{ }^{*}$ indicate significant at $1 \%, 5 \%$ and $10 \%$ level respectively. 
dataset. Furthermore, before proceeding to test panel regression models, diagnostic test were conducted. The variance inflation factor results indicates the absence of multicollinearity in the models since the coefficient of VIF is less than 10 and the mean is less than 5 (Hair et al, 2014) and any autocorrelation and heteroskedasticity problem were treated accordingly.

\section{Empirical Result with Firm Value as the Dependent Variable}

Table 3 explicates the coefficients estimates of the analysis for the Nigerian banks with firm value as the dependent variable.

Table 3: Result with Firm Value as Dependent Variable

\begin{tabular}{|c|c|c|}
\hline \multirow{2}{*}{} & \multicolumn{2}{|c|}{$\begin{array}{c}\text { Nigerian Banks } \\
\text { Model 1 }\end{array}$} \\
\cline { 2 - 3 } & Coef & t-stats \\
\hline \hline LD & -.0424 & $-2.02^{*}$ \\
\hline LATA & -.1497 & $-5.13^{\text {***}}$ \\
\hline AIY & -.4150 & $-4.23^{\text {***}}$ \\
\hline SIZE & .0915 & 0.59 \\
\hline GDP & -.1975 & -1.42 \\
\hline INFL & -.3477 & $-2.48^{\text {** }}$ \\
\hline cons & -.0588 & -0.46 \\
\hline R-sqd & .2303 & 7.59 \\
\hline Prob>F & 0.3870 & \\
\hline Obs. & 0.0000 & \\
\hline Hausman & 144 & \\
\hline
\end{tabular}

Note: ${ }^{* * *}$ indicates significant at $1 \%,{ }^{* *}$ indicates significant at $5 \%,{ }^{*}$ indicates significant at $10 \%$.

The empirical model 1 indicates that the liquidity risk variable (loan to deposit ratio) has a negative and significant effect on the firm value for Nigerian commercial banks. This implies that a decrease in loan to deposit ratio by $1 \%$ will increase the firm value of banks by $4 \%$, ceteris paribus. This is consistent with theoretical prediction that suggests a negative relationship between liquidity risk and firm value. The plausible reason is that reduction in loan to deposit ratio implies less excessive lending activities of Nigerian banks which indicates low exposure to liquidity risk, hence, ensuring firm value maximization. The result suggests that banks rely on its deposit to finance its lending activities, implying that financial firms need to manage their loan growth due to excessive lending activities in order to improve the value of firm. The result is contrary to the study by $\mathrm{Du}$, Wu and Liang (2016) who found a significant positive relationship. Additionally, the liquid asset to total assets has a negative significant relationship with firm value of Nigerian banks. This suggest that a decrease in liquid asset ratio by $1 \%$ will improve the firm value of banks by $15 \%$, ceteris paribus. The implication is that holding high liquid assets imposes an opportunity cost on banks, leading to low liquidity risk and firm value maximization.

Hence, banks can invest excessive cash, focus on revenue diversification, implying that firm value improves with lesser exposure of banks to liquidity risk. The net interest margin has a negative significant effect on firm value at $1 \%$ significance level. This suggest that a decrease in NIM of Nigerian banks by $1 \%$ will increase the firm value by $41 \%$, ceteris paribus. The implication is that high interest rate increases the cost of loans and the type of interest rate adopted by banks influence the non-performing assets. An increase in interest rate leads to higher interest payment for the variable rate loan and more expensive follow-up financing which results to decrease in the banks' earnings. Therefore, banks have to closely monitor interest rate fluctuations in order to improve firm value. Contrary to expectation, the GDP has a negative significant effect on firm value. Implying that decrease in the growth of GDP by $1 \%$ will improve the value of firm by $35 \%$, ceteris paribus. However, the asset interest yield, size of banks and rate of inflations has no significant influence of the firm value of commercial banks in Nigeria.

\section{Empirical Result with ROA as the Dependent Variable}

Table 4 explicates the coefficients estimates of the analysis for the Nigerian banks with return on asset as the dependent variable.

The empirical model 2 indicates that the loan to deposit ratio has a negative and significant effect on return on asset for Nigerian banks. This implies that a decrease in loan to deposit ratio by $1 \%$, the return on asset of Nigerian banks will increase by $4 \%$, ceteris paribus. The implication is that high loan to deposit ratio suggests loan growth of the Nigerian banks, exposing the banks to high liquidity risk and decreased profitability simultaneously. The result implies that reduction in excess liquidity and aggressive lending activities will limit the exposure of banks to liquidity risk and then improve the return on asset. High loan to 
Table 4: Result with Return on Asset as Dependent Variable

\begin{tabular}{|c|c|c|}
\hline & \multicolumn{2}{|c|}{$\begin{array}{c}\text { Nigerian Banks } \\
\text { Model } 2\end{array}$} \\
\hline & Coef & t-stats \\
\hline$L D$ & -.0435 & $-2.01^{*}$ \\
\hline LATA & .0456 & $2.29^{* \star}$ \\
\hline NIM & -.2663 & $-2.27^{\star *}$ \\
\hline$A / Y$ & .3983 & $2.67^{\star *}$ \\
\hline SIZE & .0239 & 0.31 \\
\hline$G D P$ & .2653 & $7.20^{* * *}$ \\
\hline INFL & .0708 & $2.78^{* *}$ \\
\hline _cons & .0100 & 0.48 \\
\hline R-sqd & 0.1370 & \\
\hline Prob $>F$ & 0.0000 & \\
\hline Obs. & 144 & \\
\hline Hausman & REM & \\
\hline
\end{tabular}

Note: ${ }^{* * *}$ indicates significant at $1 \%,{ }^{* *}$ indicates significant at $5 \%,{ }^{*}$ indicates significant at $10 \%$

deposit ratio indicates the reliance of banks on deposits to finance its lending activities, thereby reducing banks liquidity. This findings is supported by (Kosmidou et al., 2008; Arif \& Anees, 2012; Alzorqan, 2014; Bekele, 2015; Petria, Capraru \& Ihnatov, 2015) and contrary to the study of (Filip, 2016) who found a significant positive relationship. The liquid asset to total asset ratio has a positive significant impact on return on asset of Nigerian banks, suggesting that a $1 \%$ improvement in liquid asset ratio, the return on asset will increase by $4 \%$, ceteris paribus. The implication is that when banks hold high liquid asset, it reduces exposure to liquidity which results in improved return on assets. Further study suggest that when banks use liquid assets or much external funding to meet the demand of fund, banks cost of funding increases which consequently affects banks profitability. This is contrary to the findings by (Toby, 2008; Bordeleau \& Graham, 2010; Arif \& Anees, 2012 and Rahman \& Saeed, 2015).

Furthermore, the net interest margin has a negative significant effect on $R O A$ of Nigerian banks, implying that a decrease in NIM by $1 \%$ will improve the return on asset by $26 \%$, ceteris paribus. The implication is that increase in the cost of borrowed funds and earning assets financed by paying liabilities will negatively affects the return on asset of banks. The result is consistent with the findings of (Aruwa \& Musa, 2014; Ngalawa et al., 2013) who found a negative significant relationship. Also, the asset interest yield has a positive significant impact on $R O A$ of Nigerian banks, implying that a $1 \%$ improvement in asset interest yield, the return on asset will increase by $29 \%$, ceteris paribus. The GDP growth rate and inflation rate both has a positive significant impact on return on asset, suggesting that a $1 \%$ improvement in both GDP and inflation will increase return on assets by $26 \%$ and $7 \%$ respectively, ceteris paribus. This consistent with prior studies such as (Tingbani, 2015; Campello et al., 2012) for GDP growth and Yousfi (2014) for inflation rate. The positive association between GDP and profitability is consistent with theoretical prediction that suggest that banks profit improve and respond to positive and favourable economic growth. The bank size has no significant effect on $R O A$ for Nigerian banks.

\section{Empirical Result with ROE as the Dependent Variable}

Table 5 reports the coefficients estimates of the analysis for the Nigerian banks with return on equity as the dependent variable.

Table 5: Result with Return on Equity as Dependent Variable

\begin{tabular}{|c|c|c|}
\hline & \multicolumn{2}{|c|}{$\begin{array}{c}\text { Nigerian Banks } \\
\text { Model } 3\end{array}$} \\
\hline & Coef & t-stats \\
\hline$L D$ & -1.3858 & $-1.88^{*}$ \\
\hline LATA & -2.1489 & $-3.60^{\star \star \star}$ \\
\hline NIM & -.0113 & -0.06 \\
\hline$A / Y$ & .1875 & 0.97 \\
\hline SIZE & .4233 & 0.43 \\
\hline$G D P$ & 7.9004 & $2.81^{* *}$ \\
\hline INFL & -.1567 & -1.09 \\
\hline _cons & -.4464 & -0.22 \\
\hline R-sqd & 0.0233 & \\
\hline Prob $>F$ & 0.0000 & \\
\hline Obs. & 144 & \\
\hline Hausman & REM & \\
\hline
\end{tabular}

Note: ${ }^{* * *}$ indicates significant at $1 \%,{ }^{* *}$ indicates significant at $5 \%,{ }^{*}$ indicates significant at $10 \%$.

The findings from empirical model 3 indicates that the loan to deposit ratio has a negative and significant effect on return on equity of Nigerian banks at $1 \%$ significance level. This implies that a decrease in loan to deposit ratio by $1 \%$, the return on equity of Nigerian banks will increase by $138 \%$, ceteris paribus. The plausible reason for this is that if the market for 
deposits is reasonably competitive, then greater liquidity will tend to be negatively associated with interest margin and decline in profitability simultaneously. However, review of literature suggest that decline in excessive lending (i.e. lower loan to deposit ratio) will limit the exposure of commercial banks to liquidity risk and then improve the return on equity. This findings is supported by (Kosmidou et al., 2008; Arif \& Anees, 2012; Alzorqan, 2014), and contrary to the study by (Filip, 2016) who found a positive relationship. The liquid asset to total asset ratio has a negative significant impact on return on equity of Nigerian banks, suggesting that a decrease in liquid asset ratio by $1 \%$ will improve the return on equity by $214 \%$, ceteris paribus. The implication is that banks with higher financing gap ratio must use its cash, selling liquid assets and much external funding to fund this gap. It consequently increases their cost of funding and reduces profitability. This is consistent with the findings by (Toby, 2008; Bordeleau \& Graham, 2010; Arif \& Anees, 2012; Rahman \& Saeed, 2015). Furthermore, the net interest margin and inflation rate both have a negative and insignificant effect on ROE of Nigerian banks. The asset interest yield and bank size both have an insignificant positive relationship with return on equity. The GDP growth rate has a positive significant impact on return on equity, suggesting that a $1 \%$ improvement in gross domestic product will increase return on equity by $790 \%$, ceteris paribus. This consistent with prior studies such as (Tingbani, 2015; Campello et al., 2012) for GDP growth.

\section{IMPLICATIONS}

The empirical findings of this study accentuates on the need for banks to adhere to prudential and regulatory guidelines and ensure corporate management with respect to liquidity exposure that is capable of critically affecting banks profitability and firm value. From a policy perspective, this study suggests that the policymakers should bear in mind the trade-off between the opportunity cost of holding low-yielding liquid assets and resilience to liquidity shocks. They should adopt capital regulation, official supervision and restriction on bank activities to improve the performance of the banking sector. This study paves the way for more detailed studies into controlling the liquidity risk and to extending the current empirical model to incorporate other causes of liquidity risk. However, in order to initiate effective decisions, managers have to understand the interplay of the risk factors in the external and internal context, content, process and forces for and against financial performance. It is also expected that financial firms should assume the deterministic and practical scenarios with respect to interest rate risk. It is vital that banks develop the regulatory insights in the management of interest rate risk to ensure that risks faced across business activities and on an aggregate basis are within the stipulated risk appetite of the banks, thereby avoiding ineptitude and poor financial performance which negatively affects its returns. Finally, the current study has focused primarily on earning of the bank as measure of the performance of bank. Further research may take a broader view of the performance and can also include economic factors.

\section{CONCLUSION}

The recent global crisis has shown that banks, as major players in the financial universe, need to adjust their aims for profitability to ensure coverage against liquidity risk and interest rate risk. The general lack of liquidity during this era revealed the latent vulnerabilities of banks as banking sectors witness an historical period of global financial architectural reform. This study examines the effect of liquidity risk and interest rate risk on profitability and firm value in the Nigerian banking sector. The panel data estimation was employed with a time-series of 9-years covering 2009 to 2017 and cross-sections of 16 commercial banks from Nigeria. Hence, to the best of the researcher's knowledge, this study is the first to assess the impact of liquidity risk and interest-rate risk, profitability and firm value as a comparative study on Asean economies and the Nigerian commercial banks. It is believed that the findings of this empirical study are valuable for analysts, investors, managers and scholars.

The role of liquidity risk and the volatility of interest rate risk are important issues that was raised in this empirical research and how it can possibly influence the profitability and firm value in the banking sector under the influence of other important macroeconomic indicators such as GDP growth and the rate of inflation. Hence, the empirical results for Nigerian banks indicates that loan to deposit ratio, liquid asset ratio, net interest margin and GDP have a negative significant relationship with firm value while the bank size and inflation both have a negative but insignificant relationship with firm value Nigerian banks. This study also examined the influence of liquidity risk and interest-rate risk on bank profitability and the empirical result for Nigerian banks indicates that loan to deposit ratio have a negative and significant influence on bank 
return on asset while the liquid asset ratio have a positive significant impact on return on asset. The net interest margin have a negative significant effect while asset interest yield have a positive significant effect on return on asset. The size of banks was found to positive but insignificant while GDP growth and inflation have a positive and significant relationship with return on asset of Nigerian banks. Furthermore, the findings revealed that the liquidity risk (loan to deposit ratio and liquid asset ratio) have a negative and significant effect on return on equity of Nigerian banks. While other variables is found to be insignificant, the GDP growth is found to have a positive significant effect on return on equity for Nigerian commercial banks.

The recommendation for future studies suggest that further research can explore the risk taking behaviour of financial firms on profitability and the value of firm. Moreover, future study can also explore this dynamic relationship as a comparative study between emerging, developing and developed economy in order to give it wider research coverage.

\section{REFERENCES}

Abreu, M. \& Mendes, V. (2001). Commercial bank interest margins and profitability: evidence from some EU countries, paper presented at the Pan-European Conference Jointly Organised by the IEFS-UK \& University of Macedonia Economic \& Social Sciences, Thessaloniki, 17-20 May.

Acharya, V., \& Naqvi, H. (2012). The seeds of a crisis: A theory of bank liquidity and risk taking over the business cycle. Journal of Financial Economics, 106(2), 349-366. https://doi.org/10.1016/j.jfineco.2012.05.014

Akella, S. R., \& Greenbaum, S. I. (1992). Innovations in interest rates, duration transformation, and bank stock returns. Journal of Money, Credit and Banking, 24(1), 27-42. https://doi.org/10.2307/1992789

Akhtar, M. F., Ali, K., \& Sadaqat, S. (2010). Factors influencing the profitability of Islamic banks of Pakistan. International Research Journal of Finance and Economics, Issue 66, 126132.

Akhtar, M. F., Ali, K., \& Sadaqat, S. (2011). Liquidity risk management: a comparative study between conventional and Islamic banks of Pakistan. Interdisciplinary Journal of Research in Business, 1(1), 35-44.

Akhtar, S. (2007). Pakistan: changing risk management paradigmperspective of the regulator. In ACCA Conference-CFOs: The Opportunities and Challenges Ahead, Karachi (p. 8).

Albertazzi, U., \& Gambacorta, L. (2009). Bank profitability and the business cycle. Journal of Financial Stability, 5(4), 393-409. https://doi.org/10.1016/j.jfs.2008.10.002

Alper, D., \& Anbar, A. (2011). Bank specific and macroeconomic determinants of commercial banks profitability: Empirical evidence from Turkey. Business and Economic Research Journal, 2 (2), 140-152.

Al-Tamimi, H., Miniaoui, H., \& Elkelish, W. W. (2015). Financial risk and Islamic banks performance in the Gulf Cooperation Council (GCC). Working Paper Series in Business Studies, 1, $1-18$.
Alzorqan, S. T. (2014). Bank liquidity risk and performance: an empirical study of the banking system in Jordan. Research Journal of Finance and Accounting, 5 (12): 155, 64.

Arif, A., \& Anees, A. N. (2012). Liquidity risk and performance of banking system. Journal of Financial Regulation and Compliance, 20(20), 182-195. https://doi.org/10.1108/13581981211218342

Ariffin, A. F., \& Tafri, F. H. (2014). The Impact of Financial Risks on Islamic Banks Profitability. In International Conference on Business, Sociology and Applied Sciences (ICBSAS'14) March (pp. 26-27).

Aruwa, S. A., \& Musa, A. O. (2014). Risk components and the financial performance of deposit money banks in Nigeria. International Journal of Social Sciences and Entrepreneurship, 1(11), 514-522.

Athanasoglou, P., Brissimis, S. N., \& Delis, M. D. (2008). Bankspecific, industry-specific and macroeconomic determinant of bank profitability. Journal of International Financial Markets, Institutions and Money, 121-136. https://doi.org/10.1016/j.intfin.2006.07.001

Barth, J. R., Caprio, G., \& Levine, R. (2004). VBank Supervision and Reg\% ulation: What Works Best? V. Journal of Financial intermediation, 13, 205-248. https://doi.org/10.1016/j.jfi.2003.06.002

Bekele, B. (2015). The Nexus between Bank Specific Risk Management Practice and Financial Performance: A Study on Selected Commercial Banks in Ethiopia. https://doi.org/10.2139/ssrn.2841206

Berger, A. N., \& Bouwman, C. H. (2009). Bank liquidity creation. The review of financial studies, 22(9), 3779-3837. https://doi.org/10.1093/rfs/hhn104

Bhullar, P. S \& Bhatnagar, D. (2013). Theoretical framework EV vs. Stock price - A better measurement of firm value. International Journal of Commerce, Business and Management, 2(6), pp. 335-343.

Bordeleau, É., \& Graham, C. (2010). The impact of liquidity on bank profitability (No. 2010, 38). Bank of Canada working paper.

Bourke, P. (1989). Concentration and other determinants of bank profitability in Europe, North America and Australia. Journal of Banking \& Finance, 13(1), 65-79. https://doi.org/10.1016/0378-4266(89)90020-4

Brunnermeier, M. K. (2009). Deciphering the liquidity and credit crunch 2007-2008. Journal of Economic perspectives, 23(1), 77-100. https://doi.org/10.1257/jep.23.1.77

Campello, M., Giambona, E., Graham, J. R. \& Harvey, C. R. (2012). Access to liquidity and corporate investment in Europe during the financial crisis. Review of Finance, 16(2), 323-346. https://doi.org/10.1093/rof/rfr030

Ćurak, M., Pepur, S., \& Poposki, K. (2013). Determinants of nonperforming loans-evidence from Southeastern banking systems. Banks \& Bank System, 8(1), 45-54.

Demirgüç-Kunt, A., \& Huizinga, H. (1999). Determinants of commercial bank interest margins and profitability: some international evidence. The World Bank Economic Review, 13(2), 379-408. https://doi.org/10.1093/wber/13.2.379

Diamond, D. W. (1984). Financial intermediation and delegated monitoring. The review of economic studies, 51(3), 393-414. https://doi.org/10.2307/2297430

Diamond, D. W., \& Rajan, R. G. (2001). Liquidity risk, liquidity creation, and financial fragility: A theory of banking. Journal of political Economy, 109(2), 287-327. https://doi.org/10.1086/319552

Dumicic, M., \& Ridzak, T. (2013). Determinants of banks net interest margin in Central and Eeastern Europe. Financial Theory and Practice, 37 (1), 1-30.

https://doi.org/10.3326/fintp.37.1.1 
Ebrahim, H., Kazem, Y., Nader, M., \& Reza, K. (2013). Effects of risk parameters (credit, operational, liquidity and market risk) on banking system efficiency: study of 15 top banks in Iran. Iranian Economic Review, 17(1), 1-23.

Elyasiani, E., \& Mansur, I. (1998). Sensitivity of the bank stock returns distribution to changes in the level and volatility of interest rate: A GARCH-M model. Journal of Banking \& Finance, 22(5), 535-563. https://doi.org/10.1016/S0378-4266(98)00003-X

Ferrouhi, E. M. (2014). Bank Liquidity and Financial Performance: Evidence from Moroccan Banking Industry. Business: Theory \& Practice, 15(4). https://doi.org/10.3846/btp.2014.443

Filip, B. F. (2016). Assessing the banking systems' performance and its determinants in EU28 countries. Theoretical and Applied Economics, 23(Special (I)), 260-268.

Flannery, M. J., \& James, C. M. (1984). The effect of interest rate changes on the common stock returns of financial institutions. The Journal of Finance, 39(4), 1141-1153. https://doi.org/10.1111/j.1540-6261.1984.tb03898.x

Guru, B. K., Staunton, J., \& Balashanmugam, B. (2002). Determinants of commercial bank profitability in Malaysia. Journal of Money, Credit, and Banking, 17(1), 69-82.

Hair, J. F., Black, W. C., Babin, B. J., \& Anderson, R. E. (2014). Multivariate Data Analysis ( $7^{\text {th }}$ ed.). Pearson Education Limited.

Hamadi, H., \& Awdeh, A. (2012). The determinants of banks net interest margin; Evidence from the Lebanese banking sector. . Journal of Money, Investment and Banking, (23), 85-98.

Holmström, B., \& Tirole, J. (1998). Private and public supply of liquidity. Journal of political Economy, 106(1), 1-40. https://doi.org/10.1086/250001

Hong, H., Huang, J. Z., \& Wu, D. (2014). The information content of Basel III liquidity risk measures. Journal of Financial Stability, $15,91-111$

https://doi.org/10.1016/j.jfs.2014.09.003

How, J. C., Melina, A. K., \& Verhoeven, P. (2005). Islamic financing and bank risks: the case of Malaysia. Thunderbird International Business Review, 47(1), 75-94. https://doi.org/10.1002/tie.20041

Kalluci, I. (2010). Determinants of Net Interest Margin in the Albanian banking system. Working paper series, Bank of Albania, 4, (Tirana).

Khan, M. S., Scheule, H., \& Wu, E. (2017). Funding liquidity and bank risk taking. Journal of Banking \& Finance, 82, 203-216. https://doi.org/10.1016/j.jbankfin.2016.09.005

Khrawish, H. (2011). Determinant of commercial banks performance in Jordan. International Journal of Finance and Economics, (81), 81-95.

Kolapo, F. T., \& Fapetu, D. (2015). The influence of interest rate risk on the performance of deposit money banks in Nigeria. International Journal of Economics, Commerce and Management, 3(5), 1218-1227.

Kosmidou, K. (2008). The determinants of banks profit in Greece during the period of EU financial integration. Managerial Finance, 34 (3), 146-159 https://doi.org/10.1108/03074350810848036

Kosmidou, K., Tanna, S., \& Pasiouras, F. (2005). Determinants of profitability of domestic UK commercial banks: panel evidence from the period 1995-2002. In Money Macro and Finance (MMF) Research Group Conference (Vol. 45, pp. 127).

Kwan, S. H. (1991). Re-examination of interest rate sensitivity of commercial bank stock returns using a random coefficient model. Journal of Financial Services Research, 5(1), 61-76. https://doi.org/10.1007/BF00127084
Laeven, L., Ratnovski, L., \& Tong, H. (2016). Bank size, capital, and systemic risk: Some international evidence. Journal of Banking \& Finance, 69, S25-S34. https://doi.org/10.1016/j.jbankfin.2015.06.022

Lartey, V. C., Antwi, S., \& Boadi, E. K. (2013). The relationship between liquidity and profitability of listed banks in Ghana. International Journal of Business and Social Science, 4(3).

Lifland, S. (2011). The impact of working capital efficiencies on the enterprise value option: Empirical analysis from the energy sector. Advances in business research, 2(1), pp. 57-70.

Lynge, M. J., \& Zumwalt, J. K. (1980). An empirical study of the interest rate sensitivity of commercial bank returns: A multiindex approach. Journal of Financial and Quantitative analysis, 15(3), 731-742. https://doi.org/10.2307/2330406

Mallin, C., Ow-Yong, K., \& Reynolds, M. (2001). Derivatives usage in UK non-financial listed companies. The European Journal of Finance, 7(1), 63-91. https://doi.org/10.1080/13518470121892

Marozva, G. (2015). Liquidity and bank performance. The International Business \& Economics Research Journal (Online), 14(3), 453. https://doi.org/10.19030/iber.v14i3.9218

Memmel, C., \& Raupach, P. (2010). How do banks adjust their capital ratios?. Journal of Financial Intermediation, 19(4), 509-528. https://doi.org/10.1016/j.jfi.2009.10.002

Molyneux, P., \& Thornton, J. (1992). Determinants of European bank profitability: A note. Journal of banking \& Finance, 16(6), 1173-1178. https://doi.org/10.1016/0378-4266(92)90065-8

Moro, B. (2013). The run on repo and the liquidity shortage problems of the current global financial crisis: Europe vs. US.

Naceur, S. B., \& Kandil, M. (2008). The impact of capital requirement on banks costs of intermediation and performance. Journal of Economics and Business, 61, 70-89. https://doi.org/10.1016/j.jeconbus.2007.12.001

Ngalawa, H., \& Viegi, N. (2013). Interaction of formal and informal financial markets in quasi-emerging market economies. Economic Modelling, 31, 614-624. https://doi.org/10.1016/j.econmod.2013.01.005

Nofiyanti, I. (2014). Effect of credit risk management, market risk and operational risk on banking financial performance in Indonesia. Unpublished research thesis.

Ongore, V., \& Kusa, G. (2013). Determinants of Financial Performance of Commercial Banks in Kenya. International Journal of Economics and Financial, 3(1), 237-252.

Patnaik, I., \& Shah, A. (2004). Interest rate volatility and risk in Indian banking (Vol. 4). International Monetary Fund.

Petria, N., Capraru, B., \& Ihnatov, I. (2015). Determinants of banks' profitability: evidence from EU 27 banking systems. Procedia Economics and Finance, 20, 518-524. https://doi.org/10.1016/S2212-5671(15)00104-5

Rahman, N. A and Saeed, M. H. (2015). An Empirical Analysis of Liquidity Risk and Performance in Malaysia Banks. Australian Journal of Basic and Applied Science, 9(28): pp. 80-84.

Saeed, M. H. (2013). Examining the relationship between operational risk, credit risk and liquidity risk with performance of Malaysia banks. Universiti Utara Malaysia, Unpublished Thesis.

Said, R. M., \& Tumin, M. H. (2011). Performance and financial ratios of commercial banks in Malaysia and China. International Review of Business Research Papers, 7(2), 157-169.

Saporoschenko, A. (2002). The sensitivity of Japanese bank stock returns to economic factors: an examination of asset/liability differences and main bank status. Global Finance Journal, 13(2), 253-270. https://doi.org/10.1016/S1044-0283(02)00043-1 
Sinha, P., \& Sharma, S. (2016). Determinants of bank profits and its persistence in Indian Banks: a study in a dynamic panel data framework. International Journal of System Assurance Engineering and Management, 7(1), 35-46. https://doi.org/10.1007/s13198-015-0388-9

Spathis, C., Koasmidou, K., \& Doumpos, M. (2002). Assessing Profitability Factors in the Greek Banking System: A multicriteria methodology. International Transactions in Operational Research, 9(5), 517-530. https://doi.org/10.1111/1475-3995.00371

Staikouras, Ch. and Wood, G. (2003). The determinants of bank profitability in Europe, paper presented at the European Applied Business Research Conference, Venice, 9-13 June.

Tafri, H. F., Rahman, R. A., \& Omar, N. (2009). The impact of financial risks on profitability of Malaysian commercial banks. International Journal of Social, Behavioural, Educational, Business and Industrial Engineering, 3, 1320-1334.

Tafri, H., Rahman, R. A., \& Omar, N. (2011). Empirical evidence on the risk management tools practiced in Islamic and conventional banks. Qualitative Research in Financial Markets, 3(2), 86-104. https://doi.org/10.1108/17554171111155339

Tarus, D. K., Chekol, Y. B., \& Mutwol, M. (2012). Determinants of Net Interest Margin of commercial banks in Kenya: A panel study. Procedia Economics and Finance, 2, 199-208. https://doi.org/10.1016/S2212-5671(12)00080-9

Tingbani, I. (2015). Working capital management and profitability of UK firms: a contingency theory approach (Doctoral dissertation, Bournemouth University).
Tinoco-Zermeno, M. A., Venegas-Martínez, F., \& Torres-Preciado, V. H. (2014). Growth, bank credit, and inflation in Mexico: evidence from an ARDL-bounds testing approach. Latin American Economic Review, 23(1), 8. https://doi.org/10.1007/s40503-014-0008-0

Toby, A. J. (2008). Liquidity performance relationship with Nigerian manufacturing companies (1990-2002) Finance India. Vol. II, (3), 117-131.

Triantis, A. J. (1999). Creating and managing shareholder value: A view through a real options lens. Real Options and Business Strategy: Applications in Decision Making.

Trujillo-Ponce, A. (2013). What determines the profitability of banks? Evidence from Spain. Accounting \& Finance, 53(2), 561-586. https://doi.org/10.1111/j.1467-629X.2011.00466.x

Vazquez, F., \& Federico, P. (2015). Bank funding structures and risk: Evidence from the global financial crisis. Journal of banking \& finance, $61,1-14$. https://doi.org/10.1016/j.jbankfin.2015.08.023

Wagner, W. (2007). The liquidity of bank assets and banking stability. Journal of Banking \& Finance, 31(1), 121-139. https://doi.org/10.1016/j.jbankfin.2005.07.019

Yousfi, I. (2012). Risk management practices and financial performance in Jordan: Empirical evidence form Islamic banks. International Shariah Research Academy for Islamic Finance, 6, pp. 1-24.

Zagonov, M., Keswani, A., \& Marsh, I. W. (2009). Bank Regulations and Interest Rate Risk: An International Perspective.

\section{DOI: https://doi.org/10.6000/1929-7092.2019.08.27}

(C) 2019 Ebenezer et al.; Licensee Lifescience Global.

This is an open access article licensed under the terms of the Creative Commons Attribution Non-Commercial License (http://creativecommons.org/licenses/by-nc/3.0/) which permits unrestricted, non-commercial use, distribution and reproduction in any medium, provided the work is properly cited. 